\title{
Public good in French universities: Principles and practice of the 'republican' model
}

\author{
Vincent Carpentier and Aline Courtois
}

Published in Compare A Journal of Comparative and International Education (2020)

\begin{abstract}
Drawing on 45 semi-structured interviews conducted in four public universities as part of an international comparative project, we examine the cultural, political, social and economic forces at play in the way the 'public good' is perceived, translated and debated within the French higher education context. Our findings indicate that a variety of views of the public good value/contribution of higher education co-exist, which, in a context of reform, reflect various understandings of how the principles and practices driving the French 'republican' model work or should work.
\end{abstract}

Keywords: higher education; public good; France; public service; Republican model 


\section{Introduction}

The question of the contribution of higher education (HE) to the public good has recently attracted renewed interest (Marginson 2016, 2018; Szadowski 2018; Unterhalter et al. 2018; Walker 2018). This follows three decades of policy trends towards marketisation which have progressively framed $\mathrm{HE}$ as a private good in an increasing number of countries. This was manifested in reduced public funding and the introduction of fees, justified in terms of increased employability and higher salary expectations, thus privileging the individual returns from HE over its collective and public value (Carpentier 2012). Those trends can be connected to wider problems related to the increasing domination of the private over the public, exposed by the crisis of 2008: the fragile foundation of economic growth and its connections with the increase in inequalities (Piketty 2014), the rise of private debt as well as the resurgence of nationalistic sentiments. In the world of HE, this was manifested in the form of student debt, graduate unemployment, lack of social mobility through HE, unequal differentiation of institutions (Boliver 2017) and increasing tensions regarding internationalisation (Tannock 2018; Carpentier 2010).

These issues have led to the re-emergence of the question of the contribution of HE to the public good. This contribution is understood as variable across countries, contingent on their socioeconomic environments as well as on their cultural and political historical traditions (Marginson 2016). In this context, France provides an interesting case. As the French HE system is currently undergoing a wave of reforms, an examination of how the public good value/contribution of HE is understood in the French context is particularly timely and informative.

Over the past few decades, the French HE system has incorporated elements common to neighbouring systems and described as features of the neoliberalisation of 
HE: increased institutional financial responsibilities; competitive, project-based funding; and a sharp decrease in tenured positions through rampant casualisation. However, in many respects it still constitutes a unique system. In theory, access to HE is guaranteed to all upon completion of the secondary cycle and fees are so low as to be considered 'free', including for international students (although the government recently imposed a steep increase in international student fees, which is currently being challenged by the highest legal authority in France). Attempts to change this -through the implementation of student selection and/or fees- have been met with fierce opposition (Chauvel et al. 2015). As such, the French system contrasts sharply with that of its UK neighbour, where (with differences such as significant student bursaries in Wales and no fees in Scotland) fees have become integral components of the system to the point that it is difficult to envisage that they could be seriously challenged.

In this context, while focused on the French case, the paper has a comparative significance. The exploration of the connections and tensions between the principle and practice of the French Republican model offers a distinctive context to understand the question of the public good.

This article draws on a broader comparative project examining the ways in which HE actors understand the public good and their contribution to it with key themes such as the role of the state, social justice, meritocracy and internationalisation ('Local and global public good contributions of higher education: a comparative study in six national systems'; project for the Centre for Global Higher Education led by Prof. Simon Marginson). Drawing on 45 semi-structured interviews conducted in four French universities, the paper argues that the ideal of a public service of HE is still firmly anchored in the academic workforce. However, at the same time, our interviewees acknowledged the challenges faced by the public service of HE in practice, as the 
system shifts from the traditional French republican model to a marketised model. Our conversations led them to identify emergent ways central to preserving - or redefining the public good at the national and global levels.

The first section presents the questions related to the public good in the French context, examining in particular the principles underpinning the Republican model of HE. The second section presents the study. Next, our findings are presented thematically in three sections: the idea of the public good; the public good in practice; redefinitions of the public good and how those themes are understood at the interface of the global and national dimensions. We then draw some conclusions on how the public good debates help to refine our understanding of the French context, and vice-versa.

\section{The question of the public good in HE in the French context}

\section{Bien public and service public}

Marginson (2018) argues that both the economic and the political dimension of the terms 'public good' need to be considered. The definitions of public goods, common goods and collective goods used in French economic theory draw from Samuelson's (1954) and Hardin's (1968) works and are therefore similar to those found in the Anglophone tradition: Biens publics are defined as non-excludable and non-rivalrous goods, namely goods whose usage cannot be limited to certain (e.g. paying) individuals and whose supply is not affected by consumption (while biens privés/private goods are both excludable and rival; biens communs/common goods are non-excludable but rival, or impure public goods; and biens collectifs/club goods are non-rival but excludable e.g. for the use of a given collective). Thus, in the classical economic tradition, there is little or no variation in the definition of the terms in French and English. 
However, it is debated whether 'bien public' adequately translates 'public good'. A recurring objection to the use of the term 'bien public' is that the term 'public' in French implies state intervention and in some cases signifies 'the state' (for instance 'pouvoirs publics', literally 'public powers', refers to state institutions, commonly state authorities such as the local or national government; 'service public', literally 'public service', refers to the public sector, either in the sense of public services or in reference to civil service as a profession). Following from this, discussing whether a good or service is 'public' can be considered the same as asking whether the good or service in question is or should be provided by the state. In other words, a particular political understanding overrides the economic definition of the term in the French context.

Thus, according to Beitone (2014), in French the term 'public' refers to the state in a broad sense (central state, local authorities, social services, etc.). The 'bien public' concept is tied to the idea of state-funding or state intervention. This is due to the dominant belief that what cannot be provided through the market automatically falls within the remit of the state. The French term thus carries a stronger legal or institutional connotation compared to the English term.

Coming from a legal perspective, Cartelier and Clam argue that the notion of 'bien public' in France goes beyond the economic sphere and market v. non-market distinction. Cartelier (1998) considers that a concern for economic efficiency is not the only justification for state intervention. In classical economic theory, in cases of market failure -where certain goods cannot be sufficiently or efficiently provided by the markets- state provision is necessary and justified, in the form of state-produced market goods (infrastructure) or state-produced non-market goods (administration, national defence, etc.). However certain goods such as health, culture and education are provided by the state even though there is no market failure. The justification for this, Cartelier 
argues, is not one of economic efficiency; it relies instead on the notion of 'intérêt général' (literally 'general interest', close to the idea of 'public interest' in English) and its implications of 'equity and solidarity'. Further, Clam argues that while according to classical economic theory, the state should only intervene under exceptional circumstances, in France the notion of intérêt général overrides this principle and legitimates state intervention. Thus, 'in theory as well as in institutional practice, the legitimate and organised production of the bien public in France is located at the intersection of two principles: a principle of justice and an economic principle' (Clam, 1997, 4, own tr.). The notion of intérêt général is 'the foundation stone of state action, determining its purposes and guaranteeing its legitimacy’ (Truchet 1998, own tr). It emerged in the $18^{\text {th }}$ century, when it began to replace the religiously and morally connoted notion of 'bien commun' (literally 'common good'; translated as 'club good' in classical economic theory but otherwise understood, as in English, in a normative sense) as the guiding principle of social life (see also Dardot and Laval 2014). The notion of intérêt général is at the heart of French Public Law. It is based on the idea that the state guarantees the interest of all members of society, over individual interests, and has the authority to take decisions accordingly (Clam 1997, Vinokur and Eyraud 2018). However, not all scholars agree that bien public necessarily implies state intervention and/or non-market goods. Indeed, le 'public' (as a noun) also refers to the broader notion of civil society or society at large. There are discussions of 'biens publics' which do not necessarily focus on, or imply state provision. For instance, in his works on the enclosure of knowledge, Cassier (2002) refers to 'biens publics' as goods accessible to any potential user. His definition is based on access rather than source of provision. 
The notion that the public good and state intervention are inextricably tied is interesting to test in practice, especially in a context where the welfare state is being dismantled. The following section explores the implications for HE.

\section{The French republican model of $\mathrm{HE}$ and the public good}

The missions of the French public service of HE are specified by laws in the code of education (last amended in 2013). These include: lifelong learning; research, innovation, technology transfer, expertise and policy support to address societal challenges, social needs, economic needs and sustainable development needs; employment; promotion of the human and social sciences, science and technology; participation in the construction of the European area of HE and research. ${ }^{1}$

Those missions are often associated and at times in tension with the principles of the French republican model of HE guided by the motto "Liberté, égalité and fraternitê" (liberty, equality, fraternity), which seeks to develop a meritocratic construction of elite HE (Bettahar and Choffel 2014). This meritocratic dimension is increasingly questioned as, despite the rhetoric and principles, France is characterised by low social mobility with a strong impact of parental education on children's HE trajectory (OECD 2014, 93). The French HE system has also been described as 'conservative' and one where neoliberal reform has been unevenly implemented due to its structure and to cultural attachment to the values of open and free access (Van Zanten 2019).

${ }^{1}$ Code of education Article L123-3. Modifié par LOI n²013-660 du 22 juillet 2013-art. 
Thus, questions of access, selection and institutional differentiation are key to understanding the republican model and its connections and tensions with the public good. The baccalauréat is not only the examination marking the end of secondary education but also an award giving an automatic right to access universities (but not other HE institutions). The proportion of baccalauréat holders has increased from $30 \%$ in 1985 to $80 \%$ today. This expansion was mainly driven by the rise of the vocational baccalauréats (from 6\% in 1990 to $29 \%$ today), which are considered less prestigious and draw a higher proportion of students from lower socio-economic backgrounds (Carpentier 2018).

This differentiation at secondary level is mirrored in the tripartite HE system formed by universities (mainly non-selective and public), Grandes Écoles (highly selective, public or private), and two-year vocational institutions (selective through limited capacity, often public). Non-selective public universities remain in the majority despite a decline in their share of total enrolment from $82 \%$ in the mid-1970s to $60 \%$ today. This coincided with the growth of selective public and private institutions (representing 25\% of enrolment including 10\% in the elite Grandes Écoles) on the one hand and on the other, selective two-year vocational institutions (from $6 \%$ to $15 \%$ ). In the same way as the socially unequal distribution of academic and vocational baccalauréats, this HE differentiation reflects social structures (Carpentier 2018). Social class impacts both access to HE and student attrition, with consequences for employment and social mobility. Universities are particularity vulnerable as nonselective institutions contributing disproportionally to the widening participation agenda. 


\section{Recent reforms and new challenges to the public good in practice}

Such tensions between access and success contradicting the republican ideal in practice have been used by the government to introduce prerequisites for university admission in 2018. This caused heated debates and a wave of protests. Supporters of the reform denounced the student drop-out problem as masked social selection. Critics considered the reform as a covert introduction of social selection within the university and a threat to the principle of the meritocratic model. In particular, they argued that prerequisites would lead to a selection based on social class differentiation. Moreover, many considered student drop-out to be a direct consequence of insufficient funding rather than inadequate selection (Bodin and Orange 2018).

In April 2019, a second pivotal reform directly challenged the foundations of the French HE system by introducing a dramatic rise in fees for non-EU students, so far treated as local students. This can be interpreted as an attempt to substitute public spending (representing 90\% of universities' income) by private resources (Carpentier 2018) and thus as another manifestation of the growing marketization of the sector (Paradeise 2017). This generated debates on whether the reform was a first step towards applying cost-sharing to all students (Geisser 2018), as happened in England (Carpentier 2010), potentially threatening the republican model of free access to universities.

\section{Methods}

The broader comparative project from the Centre for Global Higher Education that the present article draws on sought to examine how the public good was understood at the institutional level and implemented in practice in a number of countries. Our approach considered the possible differences in interpretation between institutions and people within these institutions. For the French case, the sample included two large public 
research-intensive universities located in Paris and two others in large cities outside Paris. All four institutions are relatively well positioned in rankings (within the 15 highest ranked in France), research active and multidisciplinary. The interviewees included senior managers and colleagues at operational level. The interview questions sought to elicit their views on the public good and how they saw the national and institutional ways in which the public good is or might be achieved. The authors conducted 45 semi-structured interviews across the four sites, in French. We then conducted a thematic analysis which led us to identify key clusters of findings grouped around ideas of the public good (see 'Ideas of the public good' below), practices of the public good ('The public good in practice') and how the tensions between the two led to its redefinitions and re-nationalisation ('Redefinitions of the public good'; 'Renationalising the public good?'). All participants were anonymised and are here designated by their main role at the time of the interview. Academic staff involved in teaching are identified as either 'lecturer' or 'professor' to reflect the categories used in the French system. The 'lecturer' category therefore includes those whose position may be equivalent to either lecturer or senior lecturer in the UK system. The interview excerpts were all translated from French by the authors.

It is worth noting that our interviews took place between January and May 2018 in the context of reform and protests described above. Questions of selection and access came to the forefront. On the other hand, the dramatic rise in international student fees had not yet been announced.

\section{Ideas of the public good}

Various ideas of the public good emerged from the interviews. Rather than clear definitions, these were ideas and association of ideas that participants formulated when the question of the public good was raised with them. They broadly coalesced around 
four themes: what interviewees referred to as 'public service'; the idea of serving the public; the production of public knowledge; and finally, the idea of representing 'the public'.

\section{Public good as public service}

While we proposed the term 'bien public', several participants contested its use of as either too abstract, too normative, or inadequate given the realities on the ground. They often volunteered the term 'service public' (which, as noted previously, translates directly as 'public services' or 'civil service') as an alternative. For example:

While it bothers me that the university is described as a 'public good' I am very much attached - like many others I'm sure - to the university as a public service and to the services we can provide - to all the services we can provide (Senior manager, Parisian university).

The term was directly connected to state funding and the responsibilities and roles of the state, as these two excerpts illustrate:

Yes, what is the difference between the public good, something that belongs to the whole community, and public service, something that is offered, maybe, by state services? (Lecturer, Geophysics, university outside Paris).

Well I think that the French tradition is very attached to the notion of public service. Well, of course there are changes happening but I think we will remain attached to a central model for a long time, where the state is in charge of the basic state functions. So for example I don't think that developing private universities is on the agenda (Lecturer, Astrophysics, university outside Paris) Beyond the question of funding from the public purse, both participants placed the state at the centre of this "French tradition" (Beitone 2014): the state as provider and 
organiser of $\mathrm{HE}$ as one of its core functions, in the same way as other 'basic' public services.

\section{Serving the public}

Others emphasised the idea of public service as literally serving the public. In doing this, they placed university workers (rather than the state or centralised administration services) at the centre of the model, as those who literally 'serve the public' and do so with a specific 'public service' mindset:

I am a civil servant and very attached to this idea. It means that I put public service to the fore (Senior manager, university outside Paris).

It's really the place, perhaps the only place - the university - where intellectuals make themselves available to all those who want to be there, to spread knowledge. It sounds a bit rhetorical today, but it's really the case. And the fact that we dedicate ourselves to that full-time with salaries amongst the lowest in Europe shows that it is really something we do because we choose to (Professor, Physics, Parisian university).

As these excerpts illustrate, the idea is that the public service is characterised by a specific ethos, one of service and almost of self-sacrifice: university workers accept low salaries for the privilege and honour of serving others (Chatelain-Ponroy et al. 2018, 1392). This idea was emphasised by other participants, who explained how academics made up for diminished resources by working harder and inventing new ways of doing things, motivated by their commitment to service and their "passion" for teaching and research (Senior manager, Parisian university). The following excerpt is perhaps more ambiguous:

Well I am very much representative of French culture, very attached to the idea of public service. I am possibly quite ready to understand that students could 
contribute to financing their studies but I am very much rooted in the tradition that argues that knowledge is above all a public good; and therefore the transmission and the production of knowledge require for the most part people who are representative...well people who are employed by the public service and who work in the interest of the public service (Professor, Economics, university outside Paris).

This participant is among a minority favourable to cost-sharing. However, even in his desired framework, he views the idea of a 'public service ethos' as paramount to the "transmission ... and production of knowledge". The picture painted is that of a public sector staffed by individuals dedicated to the idea of public service as opposed to, say, profit. This picture is underpinned by the implicit binary between the public and the private sector.

Most interviewees revealed an identity strongly associated with public service and when asked about the mission of HE, many referred to legal documents such as the code of education setting out these missions. This attachment to serve the republic and its citizens might explain the resistance to state policies that threaten these ideals (see also Thorkelson 2018).

\section{Diversity; citizenship; access: representing 'the public'}

Other ideas of the public good that emerged from our fieldwork fitted under the broad labels of diversity, citizenship, access and public representation. The university was thus described as a space dedicated to creativity, knowledge exchange and the diversity of ideas. One participant insisted on the idea of age, gender, ethnic and social diversity and the pedagogic value of diversity:

Our lecture halls need to be heterogeneous, not homogeneous. We need people who will be able to bring different types of skills (Senior manager, Parisian university). 
This idea connects to Orange and Bodin's (2013) defence of the public university: its non-elitist nature allows it to bring together diverse populations who may not otherwise meet. In this sense, the university is more representative of the 'public' - allowing access non-selectively helps the university fulfil this mission, distinguishing it from the elitist Grandes Écoles largely populated by white middle-class students.

One interviewee understood the social dimension of public service not only in terms of access but in terms of support towards success:

But behind this public service mission - it means something that is very, very important. We have students coming in who are not very good, but there are some among them who are really not good at all but they are very motivated, they are eager, they really want to do it. So it will take time, OK, but that is indeed a public service mission (Professor, History, Parisian university).

On this topic, a Professor of Engineering noted that in comparison with Grandes Écoles, students at his university were more likely to come from working-class backgrounds, to be foreign and to be female. To him this was a sign of 'a greater opening to social diversity', all the more valuable given the excellent career prospects of engineering graduates (Professor, Engineering, Parisian university). In this sense, the low fees and low (or in the case of this particular course, comparatively low) selectivity, combined with quality training, help democratising access to a well remunerated and booming profession.

Further, several participants - in particular those with Equality and Diversityrelated responsibilities - described the university as a space to shape citizens with a concern for equality, for instance gender equality. Not only citizens, but also professionals: one explained that she was hoping to challenge the misogynist attitudes of medical doctors through specific training (Professor, Parisian university). The non- 
selective nature of French universities, coupled with a public service ethos, were understood as underpinning a broader 'public good' role, one that contributed to a more equitable, democratic society. The question of inequalities was specifically raised by an economist:

I think that one of the public service missions that is essential and at the heart of the reduction of inequalities is to avoid this binary division between a part of the population which would be overeducated and another which would not have access to a sufficient level of technicality to find its way in a knowledge society (Professor, Economics, university outside Paris).

This relates to the idea of the bien public in France combining the principle of justice and the economic principle (Clam 1997) - or the intérêt général that guarantees the interest of all members of society, over individual interests (Vinokur and Eyraud 2018). This notion of the public good starts from the collective, rather than being seen merely as that which is not private good.

\section{Production of a public/common knowledge}

A fourth idea that emerged was that of the production of public or common knowledge. One of the central questions in the debates about the public good is whether the private sector can play a role in its production (Marginson 2018). We asked our participants to reflect on this by asking them if they thought the private sector could contribute to the production of public knowledge. Several of our respondents considered that the publicly funded universities were the only places able to produce public knowledge. One referred to universities as "repositories of knowledge" and commented that "this is the public good, our common good" (Senior manager, university outside Paris). Another respondent, a scientist, compared the modes of knowledge dissemination in the private and public sectors: 
With the private sector, it's complicated, it's possible but it's complicated because they need patents, which blocks innovation because if the company have a breakthrough in a context of competition they have to keep it for themselves ... researchers need to make their breakthroughs public in the short term (Lecturer, STEM, Parisian university).

Thus, according to her, the private sector tends to 'block innovation' by keeping discoveries private; while the knowledge produced in universities is made public immediately and can therefore feed and trigger further scientific innovation. Further, and in contrast to the 'ivory tower' cliché, she described the world of industry as secretive and silent, and the academic world as one characterised by communication:

Because there is a world of silence and a world of communication (Lecturer, Parisian university).

She explained that this distinction was partly a consequence of the nature of academic work: publishing and communicating discoveries are essential to career progression. Interestingly, her account presents the public sector as innovative, dynamic, responsive and open, which contrasts sharply with the neoliberal critique of a sclerotic, inefficient sector stuck in the past and paralysed by red tape. Another participant suggested that knowledge should not only be made public, but also shared beyond borders:

I think that in relation to knowledge, we have insisted too much on this individualist dimension over the last 20 years and we are now facing a global societal challenge. We are going to have to accept that some of the knowledge that leads to technological products and therefore markets are collective goods, global public goods (Professor, Economics, university outside Paris)

This notion of global public good (Stiglitz 1999) through closer international collaborations was reinforced by another participant: 
I think that these disciplines that are working in the field of big data... have perhaps also had a leading role in the internationalisation of research, because they showed that we can work at an international scale not just as competitors but also as collaborators. And I have seen this evolution happen in the last ten years, because I was part of consortia that were created just ten years ago from scratch where we saw a very great distrust ... of this collaborative structure and finally, now, it has become a great international laboratory (Senior manager, university outside Paris).

Thus, the conception of a public good is based on the ideal of HE as a public service associated with the republican principle of equality or meritocracy. This public service value of both teaching and research at both national and global levels is seen to be intimately connected to the public sector. At the same time, the next section shows that participants identify tensions between their ideas of the public and how they perceive it in practice.

\section{The public good in practice}

\section{Decline of the 'public good'}

Participants noted a decline of the public good in practice. As already mentioned, this is one of the reasons why some of our participants contested the use of the term 'public good' and, in some cases, found it incongruous:

If you don't mind me commenting before we begin - I don't mean to introduce any form of aggressiveness but I will tell you openly that I was surprised by the object of your study ... we are in a phase, for several decades now, of frantic privatisation ... therefore this public good dimension, if there ever was one - 
and that is also a question, well today it exists even less (Lecturer, Economics, Parisian university).

This participant -an economist- mentioned several dimensions of this 'frantic privatisation' of HE, including private for-profit campus branches and fee-paying diplomas. He also pointed to the casualisation of work and the focus on 'employability' over critical thinking. His observations compounded the views of other participants who spoke of the negative impact of competitive research funding models on fundamental research, the lack of resources to support students and the rampant casualisation of academic work as further examples of the decline in universities' ability to contribute to the 'public good'.

Although not necessarily this critical, most participants agreed that universities experienced a severe funding crisis that compromised their functions. But participants spoke from different political standpoints. While naturally, political opinions and worldviews diverge within academia, the transformations recently implemented and those underway are contested and deeply divisive (Cremonini et al 2013; Thorkelson 2018). Two sets of opposing viewpoints were identifiable in our data: the view that the public service should be defended and at the other end of the spectrum, the view that forms of privatisation were desirable. Participants' discourses often constituted hybrid forms of these two positions.

\section{Public service versus marketisation? Political positioning and hybrid discourses}

Defenders of the public service tended to analyse the ongoing and attempted transformations as products of neoliberal reform. One pointed out that the state was actively orchestrating the privatisation of HE:

...the state plays a very active role in this...it's called privatisation but it's not privatisation in the classic sense in fact it's really ... a progressive decrease of the 
production of public goods by the university ... The state plays a very active role in this process in France and elsewhere (Lecturer, Economics, Parisian university).

With very few exceptions, participants were opposed to fees. One said that introducing fees was "unthinkable" and contrary to the notion of public service (Professor, History, Parisian university). The fact that we emphasised the comparative nature of the project and that we worked in the UK led to conversations where almost invariably, participants shared their disapproval of the level of fees and student debt in Anglo-Saxon systems. When asked what they thought of the employability and private benefits narrative justifying cost-sharing in England and Wales, several participants pointed to progressive income taxation as a more equitable way to share the costs and benefits of HE. Even those who acknowledged the damage caused by chronic underfunding and spoke of unsustainability did not consider fees to be an acceptable solution.

At the other end of the spectrum, we heard arguments typical of the discourses justifying privatisation and neoliberal reform. In particular, some participants argued that the French university system was saturated and unsustainable, and/or in need of modernisation. In direct opposition to the participant cited above who underlined that academics naturally shared their creations, one participant argued that knowledge had to be forcibly taken out of universities and duly patented in order to become a public good. These tensions are summarised by a participant working on knowledge transfer and interdisciplinarity:

It raises the question of whether we protect [knowledge] or not. ... On the one hand, the fact that we must protect our results, because otherwise companies exploit the results much faster than we do, it is not normal for research to be exploited, for the university not to have a return on investment. And at the same time, it is true that, on 
the other hand, research is about sharing and it is necessary that as much as possible we can share the results of knowledge. So there is a real problem here (Lecturer, Anthropology, university outside Paris).

Implicit in this perspective is the idea that the public sector is unable to turn abstract knowledge into concrete and potentially beneficial applications. Other participants sympathetic to the current reforms constructed their ideological opponents as stuck in the past and adverse to change:

The attitude of saying no we don't care about employability, we are here to shape, to open minds with no connection to what happens after...well, it's a nostalgic view of an era when jobs where falling from the sky... (Lecturer, Physics, Parisian university).

I am quite shocked to see that students who choose the university in France, unfortunately, not in all faculties but in some, do so because they reject enterprise ... then we find ourselves with students who expect that the university remains outside civil society ... some sort of place where one can have no concern at all, hence the question of students being against selection and fees ... (Lecturer, Anthropology, university outside Paris)

These participants claimed that resistance to neoliberal reform came from a place of delusion and rejection of reality. Thus, and as noted by another participant, the question of the public good is very political:

If we ask the question of the public service mission of the university, which is another formulation of what is the role of the university in society, then I come back to the question formulated in your project: Who asks the question? And from where? Because if it is a policy-maker who raises the question from a political point of view with a social project, she/he is perfectly justified in asking what is your utility in 
terms of your public service mission for the development of community and society. But if the question comes from private actors, the ways in which the answer to that question will be used can be a totally devastating one... for instance to decide that the university in its current form does not answer what they want, i.e. to provide people who will do the work that we ask them to do (Professor, History, Parisian university).

Beyond these binaries, participants also used hybrid discourses in which they attempted to reconcile the current transformations with their ideas of public service. Overall, they were divided on the issue of selectivity, public-private partnerships and fees for international students. From these conversations different ways of preserving - or redefining - the public good emerged.

\section{Redefinitions of the public good}

\section{Employability as public good}

Concerns for 'employability' are sometimes framed as detrimental to the development of critical thinking and the survival of disciplines in the Humanities or creative arts - as a threat to the traditional idea of the university (Nixon 2011; Courtois 2018a). However, most of our participants insisted on the importance of employability and some viewed it as central to the public mission of HE. When it came to issues of measurement, the views differed from those expressed for instance in the UK, where aligning fees with expected salaries is currently discussed. The idea that salaries could be used as a proxy for employability and therefore as measurement of the value of courses was rejected:

Thank god we are not at the stage where we look at what salaries students get ... everybody knows that when you study cinema, first you won't necessarily get an open-ended contract, you may get short contracts, perhaps become intermittent 
$d u$ spectacle [special status afforded professional artists in order to mitigate for precarity]. So if we had to compute their salaries it would be complicated ... [Interviewer: yes, and even their unemployment rates...] Yes, exactly, and they will have periods where they work a lot, these will be intensive periods, then periods when nothing happens... For a computer scientist the market will look very different from how it looks to a cinema graduate ... But as long as we train them for something where there are jobs ... We want to train them so that they can go to work, so that they can flourish in that job, or change because they do not like that job - that's what we want. So ... [we don't look at] salaries, thank god (Senior manager, Parisian university).

What matters therefore is not individual salaries but rather, the capacity to empower students to find meaningful work - including in the creative industries if that is what the student chooses. In this framework, employability is acknowledged as an important feature of the mission but not as an absolute quantitative principle that the university should be subject to. This suggests a model where employability might be driven by a broader idea of the public good, loosely encompassing diversity, preservation of culture and individual self-realisation, rather than by narrowly defined private returns on investment.

\section{Privatising the public good to protect it}

Another idea that emerged as a 'hybrid' form was that diminishing access to the public good was one way of protecting it. This line of argument was typically underpinned by what could be regarded as paternalistic ideas (for example, that some students waste their time and youth at university) and the idea that scarce resources had to be used wisely. 
Yes, we can still naively think that the cheaper the fees, the more accessible the university is to a large majority. So then, where I find that there is confusion ... it's that under the pretext that university is not very expensive in France, ... far too many students want to study at university when in the end, they do not have the profile and on the contrary... I mean by that, they should turn to manual work .... Now we have students who think that university is a right, so yes, of course, it's a right, but behind that there's no point in getting degrees if there's no employability (Professor, Engineering, university outside Paris).

Further, one participant argued that transferring publicly-funded knowledge to the private sector could still be considered as part of a public service mission, if it resulted in job creation:

...if we have to give our patents to a corporation because it will create applications and create jobs and make people happier, I think that's ok. It doesn't mean we have to become a corporation. You see what I mean. We don't have to be profitable. So we go back to the idea of public good (Senior manager, Parisian university).

A participant responsible for knowledge transfer described the path towards commercialisation as a form of equal collaboration:

We have project managers per sector who can go on the field to meet lab directors. [Interviewer: So it's project detection but the projects still come first from the researchers here?] Yes, but the idea is to bring them to maturity when it is relevant and then to valorise them, either by creating start-ups or ... work with companies (Senior Manager, Parisian University).

Through this hybrid discourse, forms of privatisation (closing off access) were reconciled with the idea of the public good. In a sense, the notion of public good proves 
more malleable as a concept than that of public service. It is easier to reconcile discursively with privatisation, unequal access and neoliberal reform, for a variety of private benefits and economic benefits can indeed fall under the 'public good' category.

\section{Re-nationalising the public good?}

Limiting access to the public good contribution of HE to French (or EU) nationals and French businesses were also suggested as potential directions.

\section{Global public good and fees for international students}

The debates regarding fees for international students are located at the interface of economic, (geo)political, cultural and social considerations (Carpentier 2010). Many participants clearly rejected the idea of fees for international students citing global social justice, international cooperation, preservation of linguistic and cultural influence and other geopolitical considerations.

If we, the university, increased fees ... There are plenty of young people, where would they go? So we have a responsibility to welcome them. And it's the same for foreign students (Professor, university outside Paris).

Because that idea of internationalisation as commercial, business-like, focused on excellence ... with fees ... it's completely incompatible with HE in France (Senior manager, university outside Paris).

...We are lucky to be in a country where - the health system, well, there are lots of areas where we are very privileged ... it would be a shame to lose this, whether it's for French or international students ... if they want to continue studying for a reasonable cost (Senior manager, university outside Paris). At the other end of the spectrum, supporters of the reform questioned whether domestic taxpayers should subsidise fees for international students. Many participants felt 
conflicted between rationales which they sought to reconcile by expressing the need for a higher contribution from students who could afford it. Some interviewees supported a rise in financial contribution while stressing that this was not part of a commercialisation shift but as cost-sharing to maintain the service provided:

Today, it does not seem actually now totally out of touch to say that yes it will be necessary to charge registration fees of another amount, why? Because with internationalisation come additional services. This is to improve the reception, visibility, promotion, mission, language courses, health coverage etc. (Senior manager, Parisian university).

Some of those supporting fees insisted on the introduction of scholarships for global social justice, often based on strong assumptions regarding the links between the country of origins and the student's wealth:

I think we have to find a balance between free and almost free and find an amount that would be correct without reaching astronomical sums. We must look at where they come from... because someone who comes from Haiti will not have the same means as someone coming from the United Arab Emirates (Middle manager, university outside Paris).

Some participants distinguished between EU and non-EU students as they tried to reconcile political and financial rationales:

It does not seem absurd to charge a little more students outside the EU who come to take courses at home because here ... well it's public money, so it's also the French, European taxpayers who pay the budgets of the European Commission etc. We cannot finance all international students. However, if you have to have registration fees, I think it is imperative that they are variable and combined with scholarships (Middle manager, university outside Paris) 
As already mentioned, interviews predated the increase in fees of non-EU international students announced in April 2019. Participants in favour of increasing fees seemed to have more modest amounts in mind. The actual increase (from $€ 380$ to $€ 3,770$ ) went far beyond the top-up contribution suggested by many of them. This substantial increase might indeed represent a shift from what they saw as still being part of a public good framework towards a commercial approach. ${ }^{2}$

While participants distanced themselves from a commercial approach to international student recruitment, those in favour of fee increasefor international students clearly viewed these as separate from, and somehow less deserving of public funding than domestic students. This shift, analysed by Slama (1999) in the late 1990s, points to a re-nationalisation of the public good whereby national students are seen as deserving preferential treatment. This is how several participants seem to attempt to solve the tensions between the spaces of the public good (national, EU, global). Those attempts are based on compromises between the various economic, social, geopolitical rationales framing the public good.

\section{Nationalizing Research knowledge}

A Professor in Engineering noted the difficulty for Chinese students to find placements in French companies due to the 'industrial risk' (Professor, Engineering, Parisian university). While there was only one mention of a form of national protection of

${ }^{2}$ In October 2019, the rise in fees was deemed to be in breach of the French constitution by the Conseil Constitutionnel and at the time of writing it is unclear if or how it will be implemented. 
technical knowledge from international students across all our interviews, the issue of keeping research products within France also emerged in other accounts:

I think it's complicated because indeed it sounds like we are saying today it's open access science, everything must be [openly accessible] but that doesn't mean we shouldn't have a national policy, a European policy. Is it our duty to boost research in another country through our work? (Senior manager, Parisian university).

This participant, a senior manager with responsibilities for research, gave the example of a partnership with a Chinese corporation that went on to use the credentials of the university to penetrate the French market. Based on this example and pointing to the lack of regulations of knowledge flows, she suggested that French corporations should perhaps be the first to benefit from French research, and that job creation stimulated by French research should happen within national borders first. This indicates a view of knowledge as a finite resource - almost an excludable good, one more private than public, and one that could be renationalized.

\section{Concluding remarks}

Our study shows that France still constitutes a unique case. It uses the concept of the public good as a lens to highlight and understand its specificities. In a context of fastpaced reforms orchestrating the marketisation of the French HE sector, we found that the notion of public good was still central to the way research participants understood their roles and the function of the university. In particular, the notion of 'service public' was recurring, whereby participants suggested that their role was to provide 'a public service', free at the point of entry and accessible to all. For many interviewees, this was extended to international students, providing an interesting contrast with the English case. If we go back to the literature, this points to a distinctive way in which the public 
good of HE is perceived in France. This specificity is based, to some extent, on its association with the state (Beitone 2014) and on the ideal of a public service of HE designed to serve the intérêt général, which, as part of the republican model, is justified not only in economic terms but also in relation to social equality (Cartelier 1998). Thus, this notion of the public good starts from the collective rather than being seen as a corollary of what is not private good. Besides, it does not exclude opposition to the state if it threatens this intérêt general.

Given the context, the tension between this ideal and the current reforms was prominent in the interviews. Some participants rationalised the reform as a necessity in order to continue providing a 'public service'. When the various practices of universities were detailed (including teaching, research and industry-related activities), further tensions emerged around intellectual property, 'free-riders' (the risk that some here, foreign private corporations - benefit from HE research without contributing) and competitiveness, suggesting that in many ways, the French HE system might be at a juncture. However most participants voiced their opposition to the reforms, suggesting that maintaining a free non-selective university sector within the highly differentiated HE system was central to preserving the republican model of HE. Respondents also considered employability as part of a public service rather than driven by private returns on investment. This broader idea of the public good also loosely encompassed equality of opportunity, diversity, preservation of culture and the possibility of self-realisation (through meaningful work as well as through civic engagement) for all. Thus, it diverged markedly from the discourse of selectivity, excellence and (exclusionary) elitism characteristic of the world-class university model that has been driving the stratification of many HE systems worldwide (Hazelkorn 2015; Courtois 2018b). The 
world-class university model is also driving HE reform in France but its implementation is contested and still largely incomplete (Paradeise 2017).

Thorkelson (2018) noted that the French campus they studied retained a distinct political culture; and that neoliberal reform had not succeeded in shaping neoliberal subjectivities amongst its academics. Our study tends to corroborate this but it also points to limitations, shifts, and ambiguities. All respondents sought to defend the public service of HE although some operated a shift from the intérêt général to considering scenarios that included diminishing the public good to save the public service (selection and "controlled" marketisation, privatisation of knowledge) and forms of re-nationalisation of the public good. This points to the malleability of the notion of public good, easily reconciled with different worldviews, political standpoints and understandings of the role of the state and the importance of the collective. Interestingly, we did not observe major differences in viewpoints between disciplines, apart from the fact economists gave more precise definitions of the public and private good. Differences in viewpoints seemed to be political rather than disciplinary. Further research would be needed to understand if this is the case across the HE sector.

\section{Acknowledgment:}

The support of the Economic and Social Research Council (UK), the Office for Students (UK) and Research England (UK) (grant reference ES/M010082/1) is gratefully acknowledged along with support from the Centre for Global Higher Education (CGHE). 


\section{References}

Beitone, A. 2014. "Biens publics, biens collectifs, Pour tenter d'en finir avec une confusion de vocabulaire." Revue du MAUSS permanente, 22 avril 2014 [online]. http://www.journaldumauss.net/./?Biens-publics-biens-collectifs

Bettahar, Y. and M.J. Choffel-Mailfert. 2014. Les universités au risque de l'histoire. Principes, configurations, modèles. Nancy: Presses universitaires de Nancy/Éditions universitaires de Lorraine.

Bodin R and S. Orange. 2018. "Access and Retention in French Higher Education: Student Drop-Out as a Form of Regulation.” British Journal of Sociology of Education 39(1): 126-143.

Boliver, V. 2017. "Misplaced Optimism: How Higher Education Reproduces rather than Reduces Social Inequality.” British Journal of Sociology of Education 38(3): 423-432. Carpentier, V. (2010) "Public-Private Substitution in Higher education Funding and Kondratiev Cycles: the Impacts on Home and International Students." In Global Inequalities and Higher Education, edited by E. Unterhalter and V. Carpentier, 142-171. Houndmills: Palgrave MacMillan.

Carpentier V. 2012. "Public-Private Substitution in Higher Education: Has Cost-Sharing Gone Too Far?" Higher Education Quarterly 66(4): 363-390.

Carpentier V. 2018. Expansion and Differentiation in Higher education: the Historical Trajectories of the UK, the USA and France. Centre for Global Higher Education Working Papers, 33, London: UCL IoE.

Cartelier, L. 1998. "Existe-t-il un fondement économique à la notion de service public?" Sociétés Contemporaines 32(1): 25-35.

Cassier, M. 2002. "Bien privé, bien collectif et bien public à l'âge de la génomique." Revue internationale des sciences sociales 171: 95-110. 
Chatelain-Ponroy, S., S. Mignot-Gérard, C. Musselin and S. Sponem. 2018. "Is

Commitment to Performance-based Management Compatible with Commitment to University 'Publicness'? Academics' Values in French Universities.” Organization Studies 39(10): 1377-1401.

Chauvel, S. Clément, P., Flacher, D, Harari-Kermadec, H., Issehnane, S., Moulin, L. and U. Palheta (2015) Arrêtons les frais! Pour un enseignement supérieur gratuit et émancipateur. Paris: Editions Raisons d'agir.

Clam, J. 1997. 'Qu'est-ce qu'un bien public? Une enquête sur le sens et l'ampleur de la socialisation à l'utilité dans les sociétés complexes." Archives de Philosophie du Droit 41: 215-265.

Courtois, A. 2018a. 'From ‘Academic Concern’ to Work Readiness: Student Mobility, Employability and the Devaluation of Academic Capital." British Journal of Sociology of Education 40(2): 190-206.

Courtois, A. 2018b. “The Global ambitions of Irish Universities: Internationalising Practices and Emerging Stratification in the Irish Higher Education Sector." In The Making of Elite Universities and the Production of Elites, edited by R. Bloch, A. Mitterle, C. Paradeise and T. Peter, 127-148. Basingstoke: Palgrave Macmillan. Cremonini, L., P. Benneworth, H. Dauncey and D. Wesyerheijde. 2013. "Reconciling Republican 'Egalité' and Global Excellence Values in French Higher Education.” In Institutionalization of World-Class University in Global Competition, edited by J.C. Shin and B.M. Kehm, 99-123. Heidelberg: Springer.

Dardot, P. and C. Laval. 2014. Commun. Essai sur la révolution au XXIe siècle, Paris: La Découverte.

Geisser, V. 2018. “Le ‘double discours' des pouvoirs publics français sur l'accueil des étudiants étrangers: une si vieille histoire.” Migrations Société (30): 174, 3-15. 
Hardin, G. 1968. “The Tragedy of the Commons.” Science 162, 1243-1248.

Hazelkorn, E. 2015. Rankings and the Reshaping of Higher Education. The Battle for World-Class Excellence. Basingstoke: Palgrave MacMillan.

Marginson, S. 2016. Higher Education and the Common Good. Melbourne: Melbourne University Publishing.

Marginson, S. 2018. "Public/Private in Higher Education: A Synthesis of Economic and Political Approaches." Studies in Higher Education 43(2): 322-337.

Nixon, J. 2011. Higher Education and the Public Good: Imagining the University. London: Continuum.

Orange, S. and R. Bodin. 2013. L'université n'est pas en crise. Les transformations de l'enseignement supérieur: enjeux et idées reçues. Bellecombe-en-Bauges: Éditions du Croquant.

OECD (2014) Education at a Glance 2014: OECD Indicators. Paris: OECD Publishing. Paradeise, C. 2017. "How Effective Have Reform Policies Been in Redesigning the French Higher Education and Research System?" In Universities and the Production of Elites. Discourses, Policies, and Strategies of Excellence and Stratification in Higher Education, edited by R. Bloch, A. Mitterle, C. Paradeise and P. Tobias, 103-125. London: Palgrave-Macmillan.

Piketty, T. 2014. Capital in the 21st Century. Cambridge, MA: Harvard University Press.

Samuelson, P. 1954. "The Pure Theory of Public Expenditure.” Review of Economics and Statistics 36(4): 387-9.

Slama, S. 1999. La Fin de l'étudiant étranger. Paris: L'Harmattan. 
Stiglitz, J. 1999. “Knowledge as a Global Public Good.” In Global Public Goods:

International Cooperation in the 21st century, edited by I. Kaul, I. Grunberg and M. Stern, 308-325. New York: Oxford University Press.

Szadowski, K. 2018. "The Common in Higher Education: A Conceptual Approach." Higher Education 78: 241-255.

Tannock, S. 2018. Educational Equality and International Students. Justice Across Borders? Basingstoke: Palgrave Macmillan.

Thorkelson, E. 2018. “A Campus Fractured: Neoliberalization and the Clash of Academic Democracies in France." Anthropology and Education Quarterly 50(1): 97113.

Truchet, D. 1998. Réflexions sur l'intérêt général, Rapport public du Conseil d'État 1999. http://www.conseil-etat.fr/Decisions-Avis-Publications/Etudes-

Publications/Rapports-Etudes/Reflexions-sur-1-interet-general-Rapport-public-1999 Unterhalter, E., S. Allais, C. Howell, T. McCowan, L. Morley, O. Ibrahim and M. Oketch. 2018. "Conceptualising Higher Education and the Public Good in Ghana, Kenya, Nigeria, and South Africa." In: Proceedings of the Comparative and International Education Society (CIES) 2018 Annual Conference. Mexico City. Van Zanten, A. 2019. "Neo-liberal Influences in a 'Conservative' Regime: the Role of Institutions, Family Strategies, and Market Devices in Transition to Higher Education in France." Comparative Education 55(3): 34-366.

Vinokur, A. and C. Eyraud. 2018. "Le «Higher Education and Research Act 2017»: acte de décès du service public de l'enseignement supérieur en Angleterre?" Droit et société 98(1): 113-138.

Walker, M. 2018. "Dimensions of Higher education and the Public Good in South Africa." Higher Education 76(3): 555-569. 